\title{
Ecological Zones Degradation Analysis in Central Sudan during a Half Century Using Remote Sensing and GIS
}

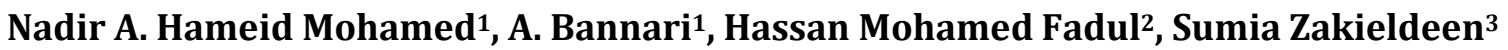 \\ ${ }^{1}$ Department of Geoinformatic, College of Graduate Studies, Arabian Gulf University, Manama, Kingdom of Bahrain \\ ${ }^{2}$ UNESCO Chair in Water Resources, Omdurman Islamic University, Khartoum, Sudan \\ ${ }^{3}$ Institute of Environmental Studies, University of Khartoum, Khartoum, Sudan \\ Email: nadir@agu.edu.bh
}

How to cite this paper: Mohamed, N.A.H., Bannari, A., Fadul, H.M. and Zakieldeen, S. (2016) Ecological Zones Degradation Analysis in Central Sudan during a Half Century Using Remote Sensing and GIS. Advances in Remote Sensing, 5, 355-371. http://dx.doi.org/10.4236/ars.2016.54025

Received: October 18, 2016

Accepted: December 16, 2016

Published: December 19, 2016

Copyright $\odot 2016$ by authors and Scientific Research Publishing Inc. This work is licensed under the Creative Commons Attribution International License (CC BY 4.0).

http://creativecommons.org/licenses/by/4.0/

(c) (i) Open Access

\section{Abstract}

Since the last assessment of ecological zones of Sudan conducted in 1958 by Harrison and Jackson, the vegetation types, cover, and its distribution have undergone remarkable changes; this change occurs in most of the predominant ecological zones, particularly those which are currently affected by environmental degradation and desertification due to climate change impact on vegetation cover and rainfall amounts and its distribution. In addition, during the last five decades, Sudan has suffered from environmental devastating changes that have undermined food security, which is strongly linked to human displacement and related conflicts. In this study, SPOTVEG NDVI data acquired between 2000 and 2010 were used to produce a vegetation cover map, which was integrated with rainfall map to produce updated ecological zones map for the study area in 2010. This map was compared to that produced in 1958 to analyze the change during the last five decades. The obtained results showed drastic change concerning different ecological zones. The desert class increased by $11 \%$. The Semi-Desert class decreased by approximately $13.2 \%$. The woodland savannah class increased by $6.8 \%$. While, the Mountain vegetation areas decreased approximately by $3 \%$. Finally, the wetland areas completely disappeared in 2010 . These results show that during the period 1958-2010, climate change impact increased desertification process, destroyed ecological zones, especially wetland, as well the ecosystems diversity in Central Sudan.

\section{Keywords}

Ecological Zones, Climate Change, Change Detection, SPOT-VEG, NDVI, Sudan 


\section{Introduction}

Since the mid 1960s, the Sahilian zone has experienced a significantly warmer weather with a systematic decrease in rainfall [1] [2] [3] [4]. This is due to climate variability impact, which can have negative effects on society and ecosystems in several ways. Indeed, this situation leads to increase widespread droughts, land degradation, desertification [5] [6], soil erosion by wind and water, mass movement, and conflicts over resources [7] [8] [9] [10]. Sudan is one of the least developed country in Africa and one of the most fragile and vulnerable areas to climate change and climate variability. An examination of its ecological zones indicates that the majority of its land is quite vulnerable to change in temperature and precipitation. Since 1980, decreasing rainfall has been accompanied by rapid increase in air temperature, approximately more than $1^{\circ} \mathrm{C}$ [10]. This warming, which is two and a half times greater than the global warming, is making "normal" years effectively drier. Between the mid of 1970s and late 2000s, summer rainfall decreased by $10 \%$ to $20 \%$ across parts of western and southern Sudan, placing already food insecure populations at greater risk [11]. Evidently, these situations have drastically affected the distribution and degradation conditions of vegetation cover, agricultural land, pasture, woodland savannah, ecological zones, water resources, and wetland [12] [13]. In addition, in the past decades, they have undermined food security and are strongly linked to poverty, civil war and human displacement [9] [11] [13] [14].

The long-term observations of spatiotemporal variations on the Earth's surface improve the understanding of variability required by numerous global change studies to explain annual and inter-annual trends to understand the climate change impact on the bio-atmosphere cycles (Salim et al., 2008). Likewise, accurate quantitative estimation of vegetation biophysical characteristics is necessary for a large variety of agricultural, ecological, and meteorological applications [15] [16]. Because of its synoptic view, global coverage and daily repetitiveness, remote sensing provide relatively inexpensive source of information. It has been recognized as a reliable and practical method for various bio-physiological environmental variables estimation, and the fragility of bio-ecosystem diversity evaluation [15] [17] [18]. Many remote sensing devices operating in the visible (blue, green and red) and near infrared (NIR) regions of electromagnetic spectrum can discriminate among several properties of vegetation cover [19]. In fact, vegetation cover assessment and mapping was one of the first uses of satellite remote sensing imagery and has been one of the most common ever since [20] [21]. In this perspective, the monitoring of Earth vegetation cover involves the utilization of vegetation indices as a radiometric measurement of spatial and temporal patterns of vegetation photosynthetic activity [22] [23]. These play an important role in the derivation of biophysical parameters, such as percentage of vegetation cover, leaf area index (LAI), absorbed photosynthetically active radiation (APAR), the rate of the biomass production, etc. Their interest lies in the detection of changes in land use and the monitoring of the seasonal dynamics of vegetation on local, regional and/or global scales. In the literature, over fifty vegetation indices were developed to measure the vegetation cover in different applications and under quite particular conditions, mainly in forestry and agriculture 
[19]. However, the Normalized Difference Vegetation Index (NDVI), which is spectroradiometric reflection measurements in the red (R) and NIR wavelengths [24], is the most popular and the most used index, especially for vegetation cover investigation at the global scale [25] [26].

Additionally, the relationship between vegetation mapping and geographic information system (GIS) is mutually beneficial for ecological system assessment and environmental modelling. The integration of auxiliary data in GIS environment with derived biophysical parameters from remote sensing images has greatly improved the vegetation mapping process [27]. Indeed, the vegetation indices are used extensively within GIS for environmental modeling purposes, climate change impact analysis, land use change detection, etc. The integration of these biophysical parameters through the GIS applications has greatly improved the ecological environmental study process and enhanced the ability to detect and to measure changes in this environment in time over long periods and vast areas [28]. For instance, the vastness of the geographical extends of our study area, which is approximately $1,236,400 \mathrm{Km}^{2}$ pose great difficulty in collection of data by a ground-based method. Therefore, remote sensing becomes an excellent alternative and the only feasible data source that can be used to map changes in vast and remote areas, particularly in developing countries where cartographic documents are inexistent, incomplete or out of date. Moreover, the synergy between remote sensing and GIS provides a valuable information for analysis, automated mapping and integration of several thematic maps to obtain useful data about environmental changes [29] [30]. The main objectives of this study are to measure the ecological zones change and degradation over the study area throughout the last five decades (1958-2010). To achieve these objectives, SPOT-VEG NDVI data acquired between 2000 and 2010 were used to produce a vegetation map that was integrated with rainfall maps in GIS to produce updated ecological zones map. Then, the latter was compared to that established in 1958.

Since Harrison and Jackson (1958), there are very few studies on the extent, causes, amount, and trend of the shift in the ecological zones. Most of those studies cover a small part of the country because they use ground based methods. The contribution of this study is that it maps the change in the ecological zones of Sudan using SPOT-VEG NDVI multi-temporal remote sensing data. The method allows for covering extensive areas of the country, and allows for comparison over time.

\section{Materials and Methods}

\subsection{Study Area}

The study area covers central, eastern, and western Sudan States, located between $10^{\circ}$ to $18^{\circ}$ North and $22^{\circ}$ to $38^{\circ}$ East (Figure 1). The population is around 31 million living in approximately $1,263,400 \mathrm{Km}^{2}$ covering the following States: Red Sea, North Darfur, West Darfur, South Darfur, North Kordofan, South Kordofan, River Nile, Northern, Kassala, Khartoum, AI Gedarif, Gezira, White Nile, Blue Nile, and Sennar [31]. Most of the population is living in the central belt where the rainfall is just sufficient along with 


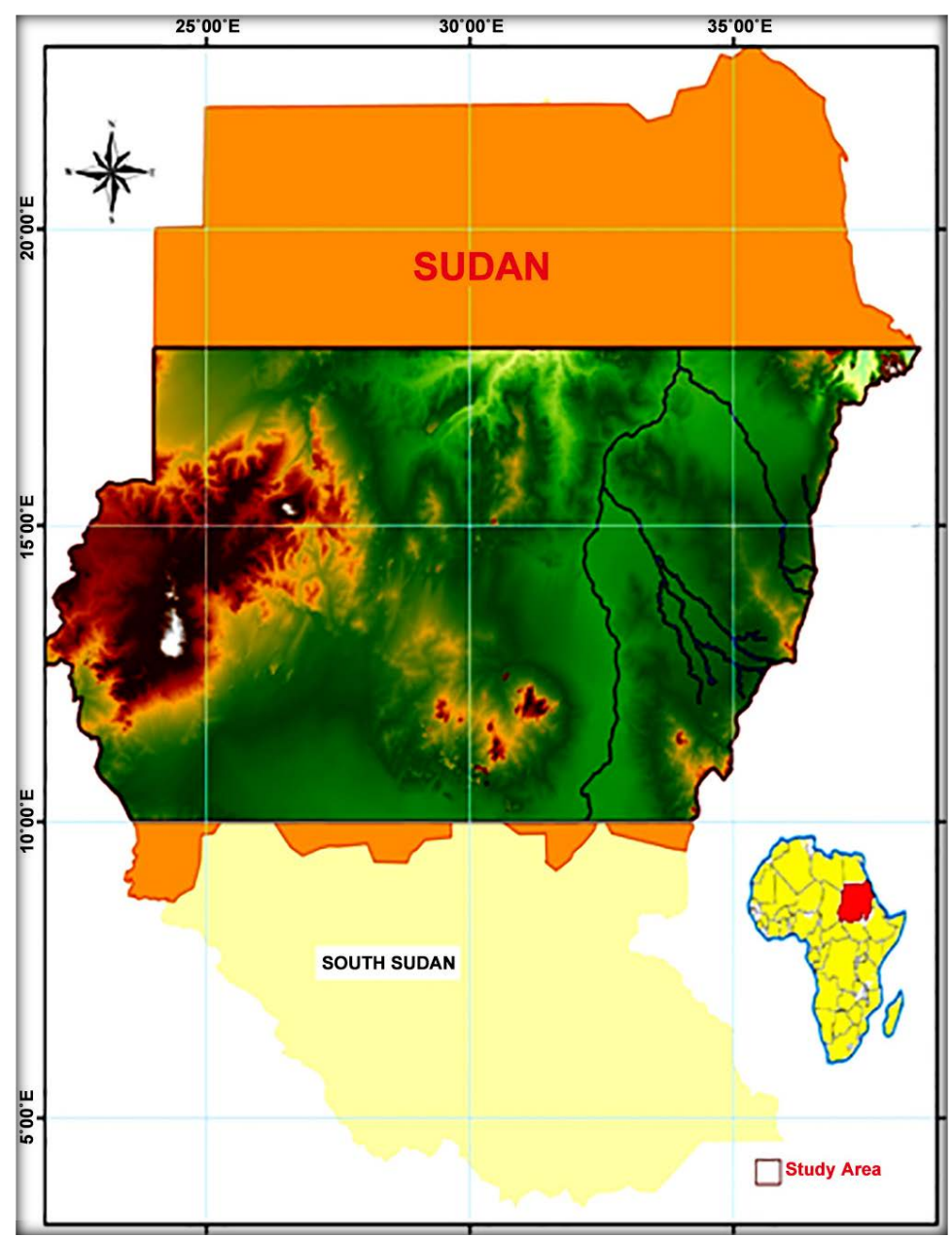

Figure 1. The study area.

many wells and small reservoirs (Hafirs). Large groups of population are dependent on agricultural production and livestock to meet basic needs as well as to generate limited household income. Due to the wide latitudinal range, the climatic zones in this area vary from hyper arid in the northern parts $\left(16^{\circ} \mathrm{N}\right)$, to areas dominated by arid and semi arid climate in central parts $\left(16^{\circ} \mathrm{N}\right.$ to $\left.13^{\circ} \mathrm{N}\right)$, the rest of the territory $\left(13^{\circ} \mathrm{N}\right.$ to $\left.10^{\circ} \mathrm{N}\right)$, is dry sub-humid.

The mean annual temperature varies between $26^{\circ} \mathrm{C}$ and $32^{\circ} \mathrm{C}$ [32]. Agriculture dominates the economy of the Sudan, about $80 \%$ of the people engaged in crop and animal production. It is practiced under diverse conditions of climate and soil and several different farming systems. The irrigated sectors are estimated at 5 million hectares including those irrigated from the Nile and its tributaries. Mechanized rain-fed sector covers areas in the central clay-plain, estimated at 6.3 million hectares. Traditional rainfed sector is estimated at 8 million hectares covering all areas under classical production where non-mechanized farming tools are predominantly used [33].

The rainfall patterns are classified in 4 seasons: monsoon season (June to September), advancing monsoon season (March to May), post monsoon season (October to No- 
vember) and winter season (December to February) [32] [34]. Rainfall usually occurs in isolated showers, which vary considerably in duration, location, and from year to year. Obviously, the number of consecutive months with adequate rainfall determines the growth season for natural vegetation as well as crops [32]. The rainfall increases from the dry north to the humid South. The annual amount is less than $100 \mathrm{~mm}$ annually in the north, averaging $200 \mathrm{~mm}$ around Khartoum, rising to $400 \mathrm{~mm}$ in central regions, and to more than $800 \mathrm{~mm}$ in the extreme southwest of the country [32] [35] [36] (Figure 2). However, there are major contrasts in rainfall and potential evapotranspiration, thus producing distinct climatic types ranging from hyper-arid, arid, semi-arid and dry sub-humid, as classified using precipitation to evapotranspiration ratio [37] [38]. Rainfall is very variable and is becoming increasingly unpredictable, with a coefficient of variation decreasing significantly from north to south, from $190 \%$ to less than $15 \%$ [9] [39].

\subsection{Ecological Map Produced in 1958}

Harrison and Jackson (1958) [40] classified the Sudan vegetation into five major ecological classes as illustrated in Figure 3. The desert-vegetation class supporting the desert conditions prevails over the northern parts of Sudan where the rainfall does not exceed $75 \mathrm{~mm}$ /year. This class is composed of vegetation confined to wadis, oasis, and narrow strip along the Nile. The semi-desert vegetation class covers regions in the south of the desert, stretched also to the northern central parts. In this region, the rainfall varies from 75 to $300 \mathrm{~mm} /$ year and the vegetation cover consists of a mixture of grasses, herbs, and occasional bushes that grow along channels (abundant species is Acacia tortilis). This region is important for grazing and browsing by nomadic herds of camels, sheep, and goats. The woodland savannah class extends across the central belt

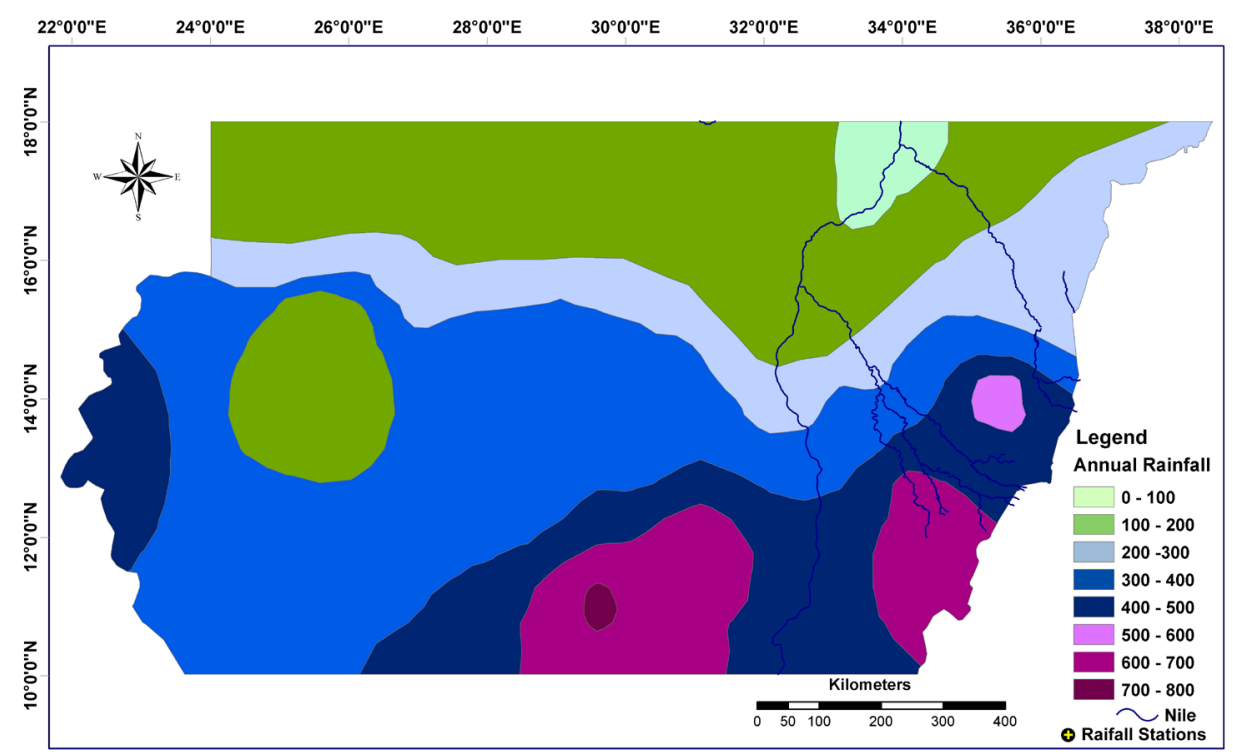

Figure 2. Mean annual rainfall isohyets for the period between 2000 and 2010 (Hameid and Bannari, 2016). 


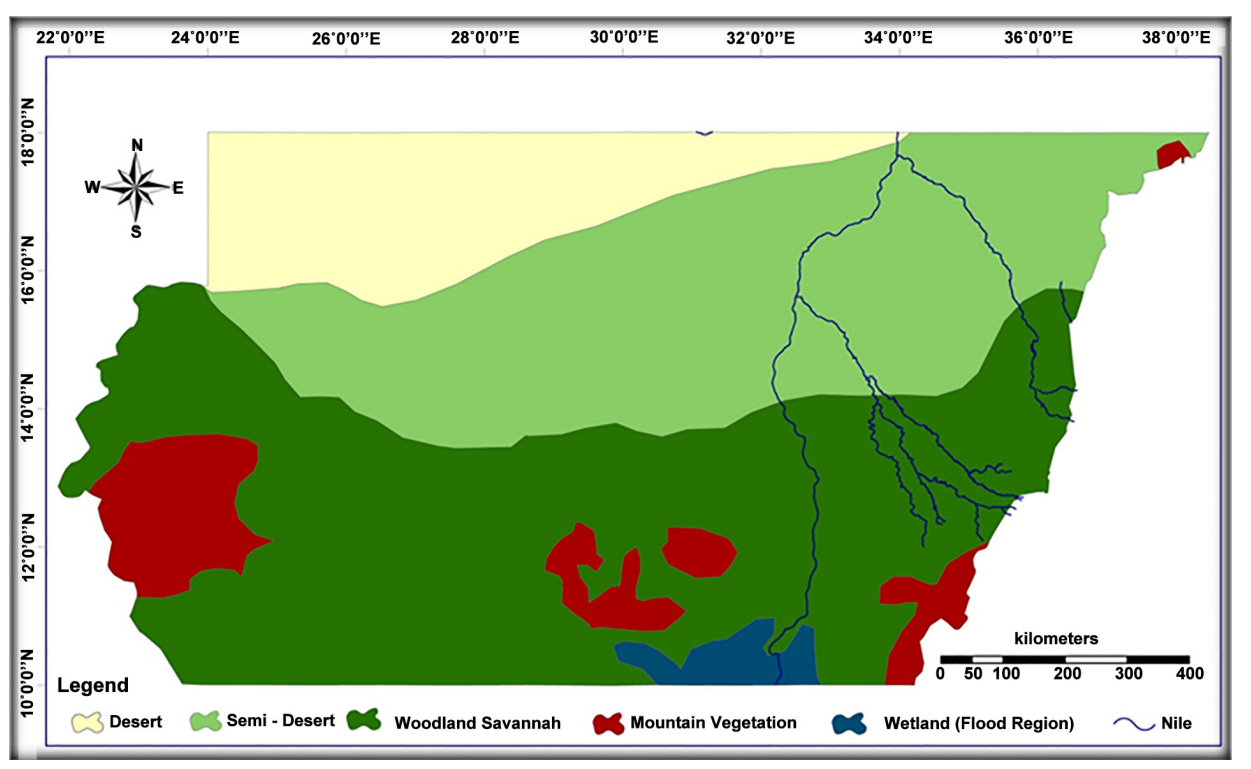

Figure 3. Harrison and Jackson (1958) ecological zones map of the study area.

and covers most of the Southern States, in this area the rainfall varies from 300 to over $1000 \mathrm{~mm} /$ year. This class is divided into two main zones: the "low rainfall savannah" and the "high rainfall savannah". In the low rainfall savannah, the precipitation varies from 300 to $800 \mathrm{~mm} /$ year, and the vegetation cover is dominated by thorny Acacias and broadleaf further south (Acacia senegal, the gum Arabic tree grows in this region). The high rainfall savannah is characterized by rainfall over $800 \mathrm{~mm} /$ year, and it is dominated by vast pasture areas and productive soils with immense potential for crop production and forests. The mountain vegetation composed of tropical forest is located in areas in the Red Sea hills in the East, and Jebal Marra in the West of Darfur State. Finally, the wetlands class (flooded region) is approximately five percent of the area which is seasonally flooded by the Nile tributaries. It covers more than $21,000 \mathrm{~km} 2$; it is a vast swamp named the "Sudd" characterized by very flat topography, multiple channels and lakes, with a maze of thick emergent aquatic vegetation. This class is a unique ecosystem for wildlife, including migratory birds.

The VEGETATION (VGT) sensor is a multispectral instrument flown onboard SPOT4 and SPOT-5 satellite platforms [41]. This instrument uses the linear-array technology and thus produces high-quality imagery at coarse spatial resolution with greatly reduced radiometric and geometric distortions [42]. It was designed for vegetation and land surface characterization [43], recording the electromagnetic radiation reflectivity in four spectral bands: blue $(0.43-0.47 \mu \mathrm{m})$, red $(0.61-0.68 \mu \mathrm{m})$, NIR $(0.78-0.89$ $\mathrm{mm}$ ), and shortwave infrared (SWIR: $1.58-1.75 \mu \mathrm{m}$ ). The blue band was designed for atmospheric scattering corrections. The R and NIR are particularly well adapted to describe the vegetation photosynthesis activity, while the SWIR is sensitive to soil and vegetation cover and moisture content, which improves the discrimination between vegetation and other land cover classes. The VGT instrument provides global coverage with a daily temporal resolution since 1998, enabling the observation of long-term en- 
vironmental and climate changes on a regional and worldwide scale [44] [45] [46]. It covers a swath width of $2250 \mathrm{~km}$ with $1 \mathrm{~km}$ pixel size, following a sun-synchronous circular orbit at $830 \mathrm{~km}$ altitude under an inclination of $98.7^{\circ}$. The calculated NDVI time series data with this sensor were used in this study.

SPOT-VGT provides three different standard products which are VGT-P (physical product), VGT-S1 (daily synthesis product) and VGT-S10 (10-day synthesis product). The VGT-S10 data are generated by selecting the VGT-S1 pixels that have the maximum NDVI value in 10-days. This 10-day composites product is generated from the atmospherically corrected surface reflectances in the R and NIR. Indeed, these spectral bands are corrected from molecular and aerosol scattering, as well as water vapor, ozone and absorption correction through maximum value compositing [42]. The surface reflectances were corrected for band-to-band miss-registration effects and linearity of radiometric response [42]. Moreover, the SPOT-VGT cloud clearing and bidirectional reflectance correction procedures were substantially applied to reduce the noise in reflectances and, consequently, on the NDVI values [47]. The final products have a high geometrical quality using WGRS-84 as reference, suitable for multi-temporal analyses in GIS environment with other mapping documents. In this research, 396 NDVI products were acquired over our study area for the period between 2000 and 2010.

To extract the rainfall data for the considered period between 2000 and 2010, rainfall data for the period 1990 to 2010 were obtained from Sudan Meteorological Authority, twenty meteorological stations were selected based on their spatial distribution covering the entire region of interest. These are geographically located in the following regions: 2 stations (Atbara and Shendi) at far north parts in desert zone, 8 stations (HalfaGadida, Kassala, Khartoum, Wad Madani, Kosti, Al Obayid, Al Fashir and EnNahud) in the central and eastern parts of the semi-deserts zone, and the rest in the humid zone of the study area (Sennar, Gedarif, Babanosa, Abu Naama, Ed Dueim, Renk, Ed Damazin, Kadugli, Nyala and Rashad).

\subsection{Data Processing}

Three software packages were used in this research: VGT-Extract, ERDAS Image processing, and ArcGIS. The VGT-Extract facilitates the integration of SPOT-VGT products into commonly used remote sensing software for further analysis, post-processing, and visualization. As well, it was used for automatic unpack (un-compress) the product, to mosaic the data layers, to extract the geographic bounding box of the study site, and to convert the data to different formats. The ERDAS system was used to import, convert, preprocess and process SPOT-VGT NDVI products. The decadal NDVI (396 products) were integrated to produce a monthly maximum NDVI maps (total of 132 maps). The use of maximum value composites reduces some of the extraneous variability inherent in the NDVI caused by differences in atmospheric conditions [47] [48].

Furthermore, the monthly maximum NDVI maps for every year were added to produce the annual maximum product. The annual maximum image during 11 years was added to produce long term maximum map product. The process was carried out on a 
pixel-by-pixel basis and the result of the division was normally rounded to the nearest integer [26]. The study area is very large and it is difficult to select pure training sites, to overcome this problem unsupervised classification based on ISODATA algorithm was used to process the long term maximum NDVI product from 2000 to 2010 [49]. Consequently, 25 pure clusters were generated indicating various vegetation classes. The synergy among this steps and other existing vegetation maps and Africover database [50], as well Harrison and Jackson (1958) ecological zones map helped to select the most significant training sites for supervised classification [51]. The output thematic map product generated by supervised classification was filtered using the average filter ( $5 \times 5$ windows) to remove the fragmented or non-classified pixels [52], then converted to vector-polygon layer format for further analysis in GIS environment. Moreover, the spatial relationships between the derived vegetation classes and their attributes were introduced using GIS topology options.

The geographical locations of the meteorological stations and the derived vegetation map based on supervised classification were obtained from different sources and had different reference projections. Thus, ArcGIS was used to re-project the two maps in the same geographic coordinate system (Latitude and Longitude). For this purposes, the meteorological station locations documented in Excel file format were converted to point geometry feature class using COGO method. Moreover, the rainfall values measured by the twenty meteorological stations during the period 2000-2010 over the study site was interpolated using inverse distance weight (IDW) method in GIS to create the mean annual rainfall map [39]. The output cell size was selected similarly to the derived vegetation map based on VGT-NDVI spatial resolution $\left(1 \mathrm{Km}^{2}\right)$. Figure 4 illustrates data possessing flow chart.

\section{Results and Discussion}

This research focus on the evaluation of the magnitude of ecological zones changes in central Sudan throughout the last five decade using Harrison and Jackson (1958) ecological zones map as reference. Figure 5 shows the compiled long term maximum NDVI map during the last decade between 2000 and 2010 using SPOT-VGT NDVI time series data. The visual analysis of this map shows consistent stratification of vegetation cover from the very scattered class (or absent) in the north to the dense vegetation cover class in the south. In the middle of the study area, the rainfall plays an important role in the growth of vegetation cover. While, in the south and northeast as well as some patterns in the west, the vegetation cover density looks change less drastically as a function of rainfall. Indeed, these regions are irrigated from many secondary rivers originating from the Ethiopians-mountains, and from the Nile Rivers (Blue Nile, White Nile, and Atbara River). For instance, in the El-jazira region which is a triangle receiving different secondary water sources (irrigated agricultural fields) shows a constant vegetation patterns during the considered decade (2000-2010). However, in the northern areas the vegetation cover density is very low or completely absent due to very low rainfall rate caused by climate change effects [39]. 


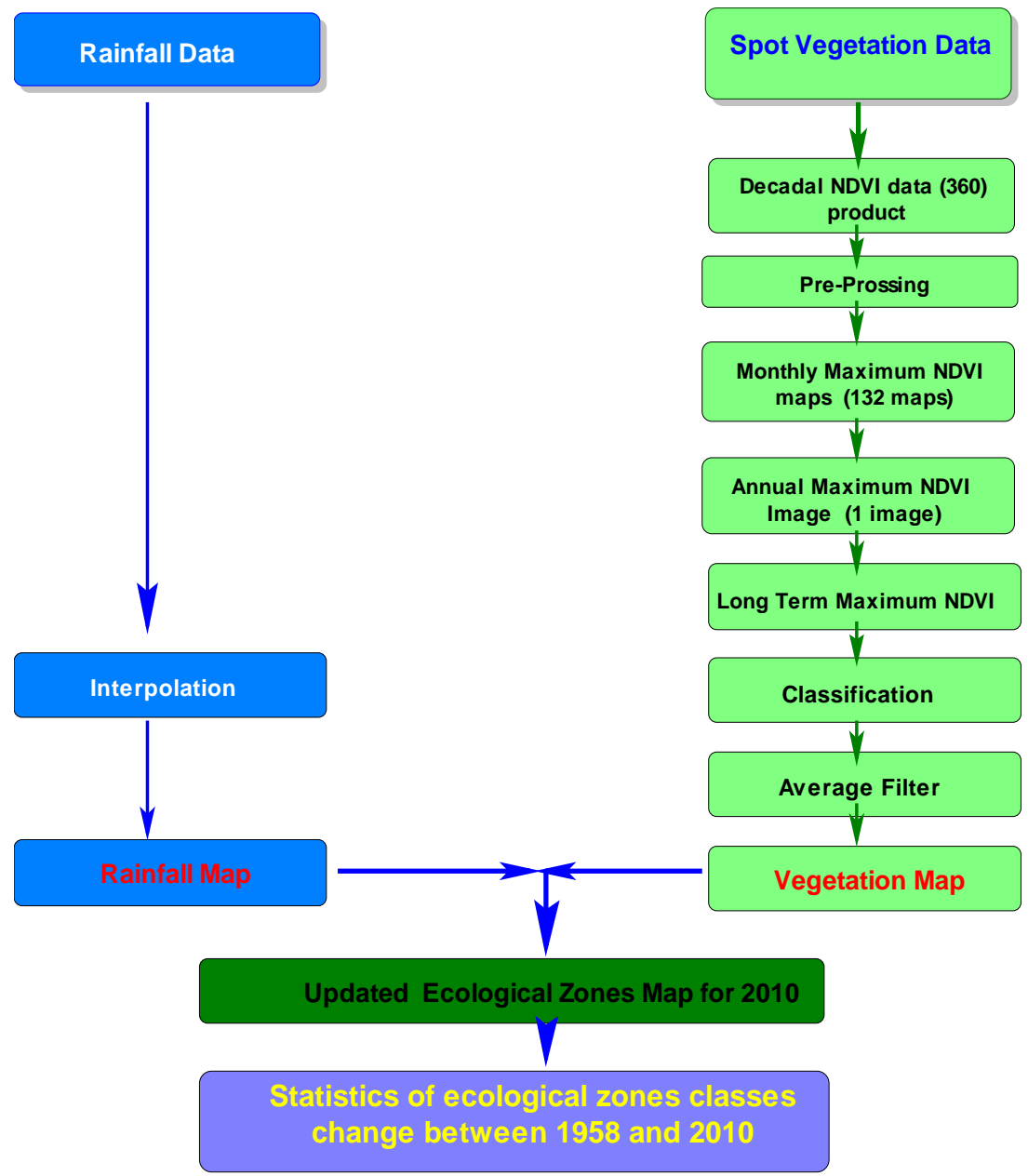

Figure 4. Data possessing flow chart.

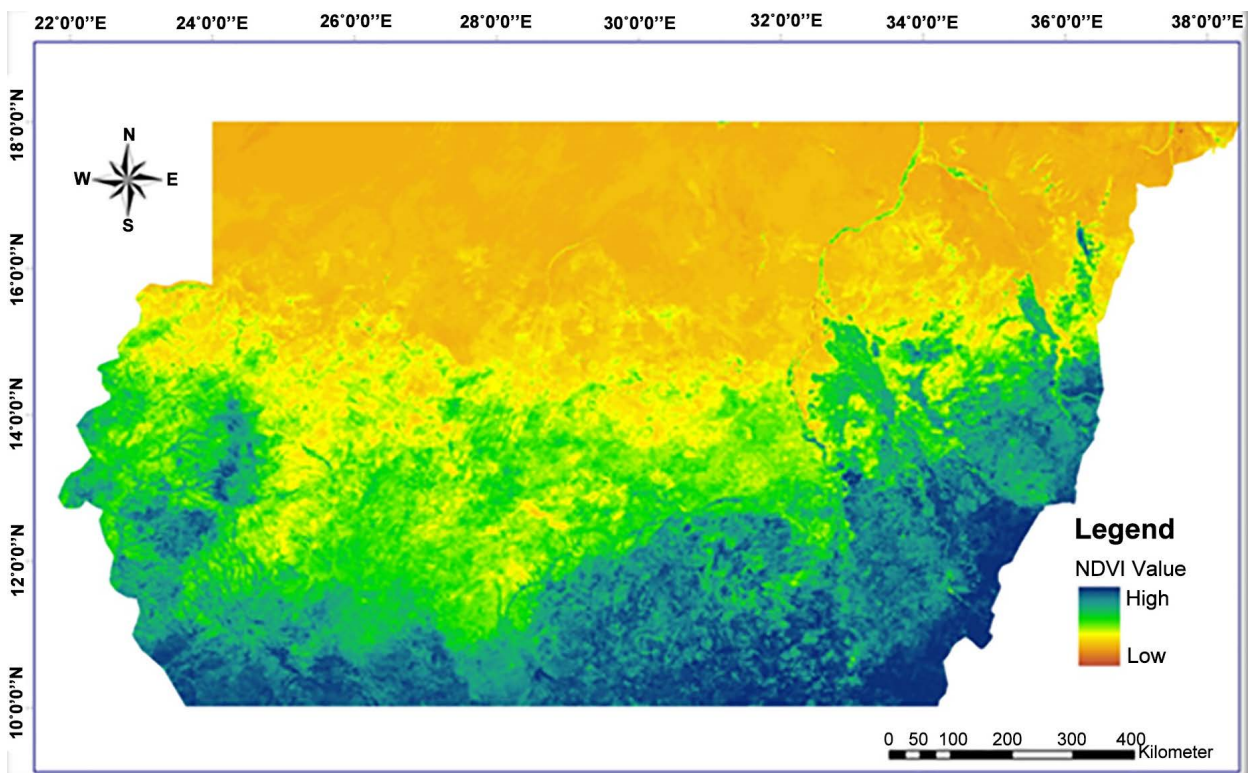

Figure 5. Long term maximum NDVI values map between 2000 and 2010. 
Figure 6 illustrated the vegetation cover map derived from the long term maximum NDVI values (2000-2010) using supervised classification. It shows the five dominated vegetation classes, such as: desert, semi-desert, low rainfall woodland savannah, high rainfall woodland savannah, and mountain vegetation. This map was integrated with the annual mean rainfall map in GIS to create the updated ecological zones map for the decade 2000-2010 (Figure 7).

The latter was superimposed on Harrison and Jackson (1958) ecological zones map (Figure 3) and compared using advanced vector analysis and post-classification change detection approaches proposed by Mausel et al. (2003) [53].

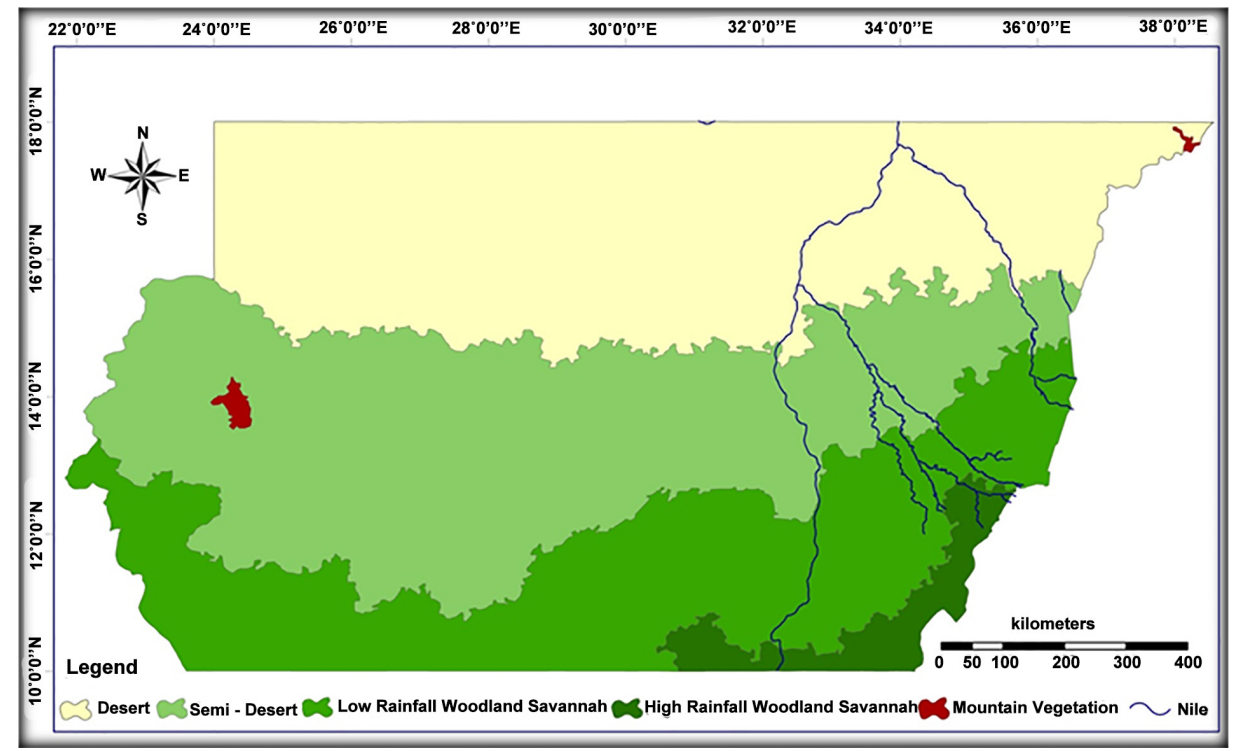

Figure 6. Vegetation cover classes map derived from the long term maximum NDVI values between 2000 and 2010 using supervised classification.

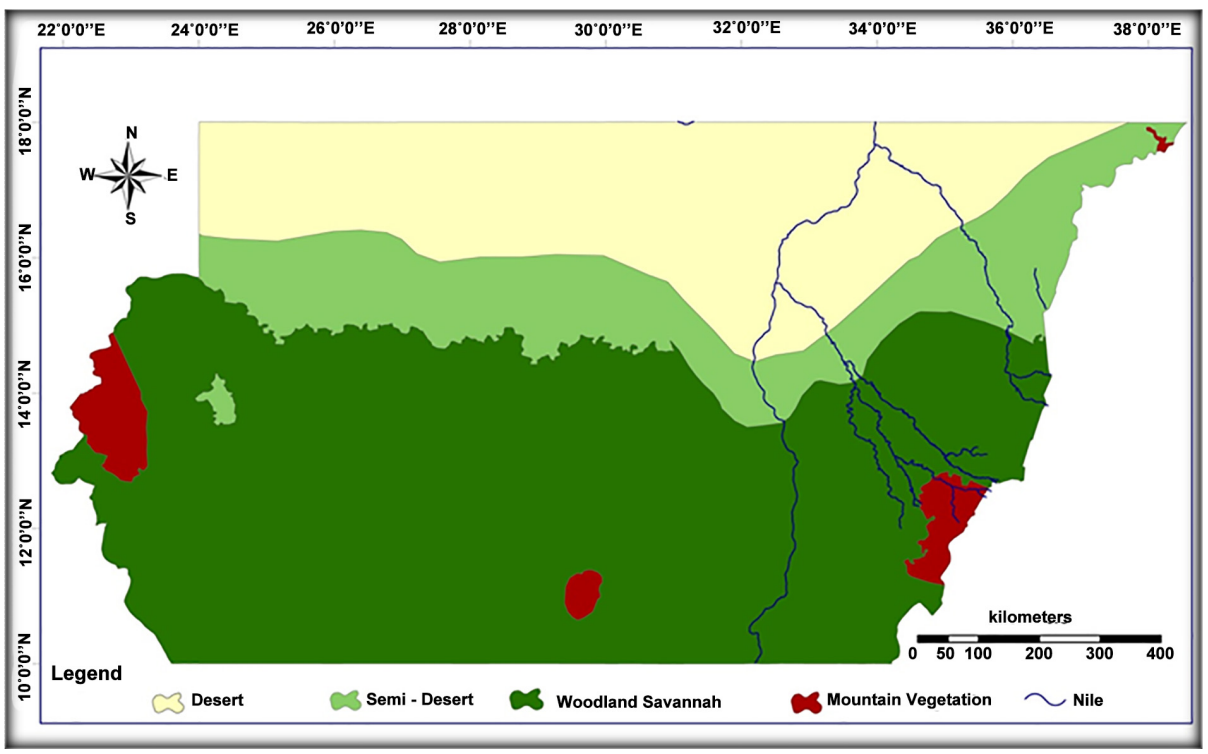

Figure 7. Derived ecological zones map updated for 2010. 
Table 1 shows the areas covered by the different ecological zones produce by Harrison and Jackson (1958) for the study area, and the areas of the updated ecological zones map in 2010 for the same study area. Along with, the statistics of ecological zones changes during a half of century. Figure 8 illustrates the calculated change in the different ecological zones in the last five decades.

The updated derived ecological zones map (Figure 7) shows a drastic change between 1958 and 2010. The first important and major observation is the complete disappearance of the wetlands (flooded region) class, which was covering in 1958 by approximately $1.7 \%$ of the total study area, $\left(21,092 \mathrm{~km}^{2}\right)$. This very significant variation is a strong indicator of climate change impact on the region. Obviously, the consequences of this change affect human activities in this region, as well the destruction and the extinction of many biological ecosystems related to this ecological class. Moreover, Table 1 and Figure 6 show that the mountain vegetation class, which is a tropical forest cover located in four different spots (NW, center, NE, and SE) in 1958, was severely decreased by approximately half, from $9301 \mathrm{~km}^{2}$ in 1958 to $5594 \mathrm{~km}^{2}$ in 2010 . Although this ecological class is located in high rainfall areas, it shows a significant degradation (around $3 \%$ of the total study area). In addition to climatic variations and impact, these forest cover zones are subject to destruction by local population. In fact, in the centersouth region, the forest cover was removed intentionally for agricultural purposes. Moreover, it was damaged by humans for wood-energy demand, for traditional material construction and as rangeland for animals. As well, the armed conflicts in Nuba

Table 1. Comparison between ecological zones change in time between 1958 and 2010.

\begin{tabular}{|c|c|c|c|c|c|}
\hline \multirow[b]{2}{*}{ Ecological Zones } & \multicolumn{2}{|c|}{ Ecological Zones in 1958} & \multicolumn{2}{|c|}{ Ecological Zones in 2010} & \multirow{2}{*}{$\begin{array}{c}\text { Change in time } \\
\text { \% from } \\
\text { study area }\end{array}$} \\
\hline & $\mathrm{Km}^{2}$ & $\begin{array}{c}\% \text { from } \\
\text { study area }\end{array}$ & $\mathrm{Km}^{2}$ & $\begin{array}{c}\% \text { from } \\
\text { study area }\end{array}$ & \\
\hline Desert & 175,308 & 13.9 & 314,076 & 24.9 & $+11.0 \%$ \\
\hline Semi-Desert & 417,297 & 33.0 & 250,196 & 19.8 & $-13.2 \%$ \\
\hline Woodland Savannah & 556,689 & 44. 0 & 643,184 & 50.9 & $+6.8 \%$ \\
\hline Mountain Vegetation & 93,014 & 7.4 & 55,944 & 4.4 & $-3.0 \%$ \\
\hline Wetland (Flooded Region) & 21,092 & 1.7 & 0 & 0 & $-1.7 \%$ \\
\hline
\end{tabular}

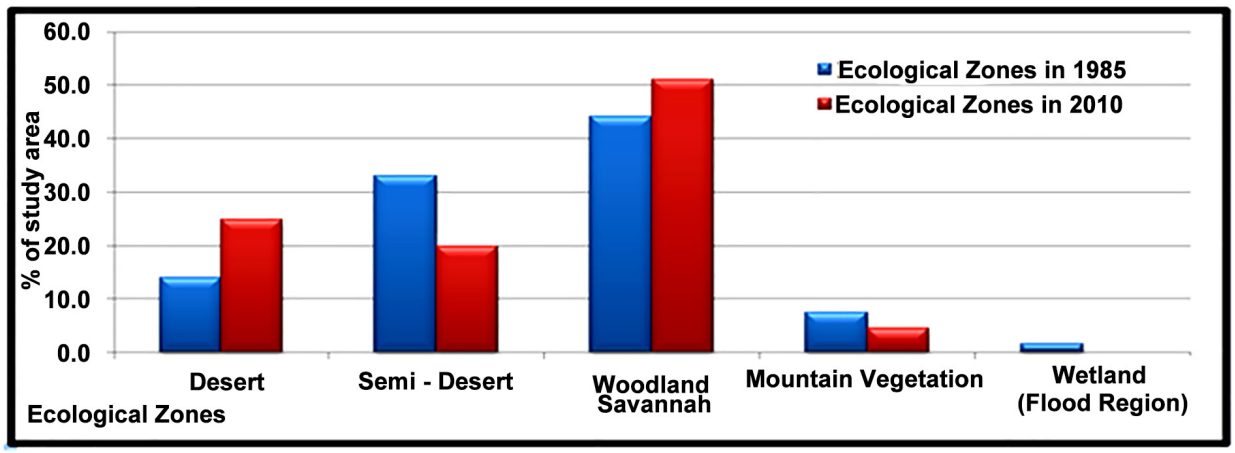

Figure 8. Statistics of ecological zones classes change between 1958 and 2010. 
Mountain, Blue Nile, and Darfur were the origin of several forest fires. Evidently, the combination of all these factors significantly contributes to the degradation of this class [14].

Unlike wetlands and mountain vegetation areas, the desert class increased significantly towards the south (north of Darfour, Kordofan, and red Sea) by $11 \%$, from $175,308 \mathrm{~km}^{2}$ to $314,076 \mathrm{~km}^{2}$. According to the Harrison and Jackson, this class was covering $13.9 \%$ of the total study area but it covers $24.9 \%$ in 2010 . The increasing extend of this class by $11 \%$ of the study area was caused by the extreme temperatures, very low rainfall rate, and disappearance of scattered vegetation that cover this area in the past. Indeed, historically the rainfall was severely reduced and the cycles of droughts affected permanently this region during the last decades [10] [11] [39], similarly all the African zones located at this geographic latitude. These conditions are automatically related to climate change, and affect not only environmental issues but also the population migration problems, food security difficulties and catalyze ethnical conflicts in central Sudan.

The comparison of semi-desert class between 1958 and 2010 shows that the total area of this class decreased relatively by $13.2 \%$ of the study area, it passed from $417,297 \mathrm{~km}^{2}$ to $250,196 \mathrm{~km}^{2}$. This lost area was substituted by the advancing desert class from the north to the center of Sudan. In the eastern zone of this class, the expansion of rain-fed agriculture has played a devastating role in removing and eliminating forest cover, shrubs, rangeland and destroy ecosystems and habitats of wild animals for the last five decades [14]. The increasing demand of the agricultural land expansion is automatically related to the rapid population growth which has direct consequences on the demand for more land for crop production, and environment degradation. Indeed, this semidesert class has been subjected to more soil erosion, desertification, and land degradation caused by climate change due to long-term droughts, highly variable rainfall, as well as overgrazing and intensive farming. Moreover, the civil war in the rural areas of these zones caused the displacement about 6 million people, approximately $20 \%$ of the Sudan population. Subsequently, one of the most significant environmental impacts of this displaced population is the severe deforestation that has occurred around the large camps in the drier parts of the country. According to USGS (2011) [11], climate change and natural resources are often assumed a key cause of conflict in Sudan.

Finally, the woodland savannah ecological class encompassing the two subclasses "low rainfall savannah and high rainfall savannah" forms the green central belt of the country, it was increased by $6.8 \%$ of the total study area. In other words, this area was enhanced from $556,689 \mathrm{~km}^{2}$ in 1958 to $643,184 \mathrm{~km}^{2}$ in 2010. This improvement has occurred at the expense of the two other missing classes; wetland and forest cover zones (4.7\% of the study area). This ecological zone benefits from a suitable geographic location that often guarantees significant rainfall rate between 400 and $800 \mathrm{~mm} /$ year (Figure 2 ), as well as from the most productive soils in Sudan. Moreover, the Nile and their tributaries irrigated the southeast and the south of this zone where is located the most irrigated agricultural lands in Sudan. Obviously, all these favorable conditions have 
guaranteed the spatiotemporal stability of this class, as well its relative enhancement in the north border. Indeed, although the rainfall rate decreased globally in this region from about $1200 \mathrm{~mm}$ /year in 1958 to $800 \mathrm{~mm}$ /year in 2010, the precipitation rate in the contact-zones between semi-desert and woodland-savannah classes in the north was increased by approximately $100 \mathrm{~mm}$ /year, as a consequence of climatic disturbances [39]. These favorable conditions have significantly contributed in the woodland class expansion by $2.1 \%$ of the study area. This result confirms previous regional-scale findings by many scientists and researchers [54] [55] [56].

\section{Conclusions}

The main objectives of this study focus on the ecological zones change and degradation in central Sudan over the last five decades (1958-2010). To achieve these objectives, SPOT-VEG NDVI data acquired between 2000 and 2010 were used to produce a vegetation map, which was integrated with the annual mean rainfall to produce a new ecological zones map for the considered decade. A comparative study between this updated map and one produced in 1958 by Harrison and Jackson were made. The obtained results showed that overall trend observed during the last 50 years indicated a large change in the recent ecological zones and the areas covered by vegetation classes compared to those mapped in 1958. The harmful impact was manifested in the disappearance of the wetlands (flooded region) class. The forest cover was severely decreased by approximately the half. The desert and semi-desert boundaries was shift southwards due to declining of precipitation, increasing of temperature. The semi-desert areas were subject to deforestation, expansion of intensive rain-fed agriculture, civil war and population displacement. The woodland savannah ecological class encompassing the two subclasses "low rainfall savannah and high rainfall savannah" forms the green central belt of the country; it was the only increased ecological zones in 2010. Its improvement has been occurred in detriment of the two other missing classes: wetland and forest cover zones.

Currently, negative impacts of global warming and climate change represent a serious sustainable development problem that affects the country. Sudan's water resource scarcity management, soil and agricultural productivity conservation, ecosystems and biodiversity protection, human social vulnerability, and public health challenges can greatly benefit from the implementation of constructive policy of adaptation to climate change. Certainly, promoting an appropriate sustainable development policy and a national management strategy will be a concerted action to reduce vulnerability to the anticipated negative impacts of climate change. According to many scientists, there is the need therefore to integrate indigenous knowledge about drought with modern scientific knowledge and technologic development for the design and implementation of best practices in climate change mitigation and adaptation strategies [57] [58] [59] [60].

\section{References}

[1] Folland, C.K., Parker, D.E. and Palmer. T.N. (1986) Sahel Rainfall and Worldwide Sea 
Temperatures 1901-1985. Nature, 320, 602-607. https://doi.org/10.1038/320602a0

[2] Janicot, S., Moron, V. and Fontaine, B. (1996) Sahel Droughts and Enso Dynamics. Geophysical Research Letters, 23, 515-518. https://doi.org/10.1029/96GL00246

[3] Nick, B. (2004) Drought in the African Sahel: Long Term Perspectives and Future Prospects. Tyndall Centre for Climate Change Research Working Paper 61.

[4] Paulo, C., Baldicero, M., Cati, V., Fabio, C., Andrea, R. and Maria, M. (2012) Dynamical Outlines of the Rainfall Variability and the ITCZ Role over the West Sahe. Atmospheric and Climate Sciences, 2, 337-350. https://doi.org/10.4236/acs.2012.23030

[5] Nicholson, S.E. (1979) Revised Rainfall Series for the West African Subtropics. Monthly Weather Review, 107, 473-487. https://doi.org/10.1175/1520-0493(1979)107<0620:RRSFTW >2.0.CO;2

[6] Lamb, P.J. (1982) Persistence of Sub-Saharan Drought. Nature, 299, 46-48. https://doi.org/10.1038/299046a0

[7] Hulme, M. (1990) The Changing Rainfall Resources of Sudan. Transactions of the Institute of British Geographers, 15, 21-34. https://doi.org/10.2307/623090

[8] Alvi, S.H. and Elagib, N.A. (1996) Study of Hydrology and Drought in the Flood Region of Sudan. Water International, 21, 76-82. https://doi.org/10.1080/02508069608686493

[9] Zakieldeen, S.A. (2009) Adaptation to Climate Change: A Vulnerability Assessment for Sudan. International Institute for Environment and Development, London.

[10] MER (2015) Climate Change Profile South Sudan. Netherlands Commission for Environmental Assessment, Dutch Sustainability Units.

[11] USGS (2011) A Climate Trend Analysis of Sudan. http://pubs.usgs.gov/fs/2011/3072/pdf

[12] HCENR (2003) Sudan 1st National Communication on Climate Change. Ministry of Environment and Physical Development, Higher Council for Environment and Natural Resources, Khartoum, Sudan.

[13] NAPA (2007) National Adaptation Programme of Action Republic of the Sudan. Ministry of Environment and Physical Development, Higher Council for Environment and Natural Resources, Khartoum, Sudan.

[14] UNEP (2007) Sudan Post-Conflict Environmental Assessment. United Nations Environment Programme, Nairobi, Kenya.

[15] Hansen, P.M. and Schjoerring, J.K. (2003) Reflectance Measurement of Canopy Biomass and Nitrogen Status in Wheat Crops Using Normalized Difference Vegetation Indices and Partial Least Squares Regression. Remote Sensing of Environment, 864, 542-553. https://doi.org/10.1016/S0034-4257(03)00131-7

[16] Houborg, R., Soegaard, H. and Boegh, E. (2007) Combining Vegetation Index and Model Inversion Methods for the Extraction of Key Vegetation Biophysical Parameters Using Terra and Aqua MODIS Reflectance Data. Remote Sensing of Environment, 106, 39-58. https://doi.org/10.1016/j.rse.2006.07.016

[17] Weiss, M. and Baret, F. (1999) Evaluation of Canopy Biophysical Variable Retrieval. Remote Sensing of Environment, 70, 293-306. https://doi.org/10.1016/S0034-4257(99)00045-0

[18] Cohen, W.B., Maiersperger, T.K., Gower, S.T. and Turner, D.P. (2003) An Improved Strategy for Regression of Biophysical Variables and Landsat ETM+ Data. Remote Sensing of Environment, 84, 561-571. https://doi.org/10.1016/S0034-4257(02)00173-6

[19] Bannari, A., Morin, D., Bonn, F. and Huete, A.R. (1995) A Review of Vegetation Indices. Remote Sensing Reviews, 13, 95-120. https://doi.org/10.1080/02757259509532298

[20] Hoffer, R.M., Stafffleming, M.D., Hof, R.M. and Mayer, K.E. (1975) Natural Resource Map- 
ping in Mountainous Terrain by Computer Analysis of ERTS-1 Satellite Data. Research Bull 919, Agricultural Experiment Station and Lab, for Applications of Remote Sensing, Purdue University, West Lafayette.

[21] Jensen, J.R. (2000) Remote Sensing of the Environment: An Earth Resources Perspective. Prentice-Hall, Upper Saddle River.

[22] Goward, S.N., Turner, S., Dye, D.G. and Liang, S. (1994) The University of Maryland Improved Global Vegetation Index Product. International Journal of Remote Sensing, 15, 3365-3395. https://doi.org/10.1080/01431169408954336

[23] Yengoh, G.T., Dent, D., Olsson, L., Tengberg, A.E. and Tucker III, C.J. (2014) The Use of the Normalized Difference Vegetation Index (NDVI) to Assess Land Degradation at Multiple Scales: A Review of the Current Status, Future Trends, and Practical Considerations. Lund University Center for Sustainability Studies (LUCSUS), and the Scientific and Technical Advisory Panel of the Global Environment Facility (STAP/GEF).

http://www.stapgef.org/stap/wp-content

[24] Rouse, J.W., Haas, R.H., Schell, J.A., Deering, D.W. and Harlan, J.C. (1974) Monitoring the Vernal Advancement of Retrogradation of Natural Vegetation. Performances from the Accumulation of Large Swath Satellite Data. Remote Sensing of Environment, 70, 293-306.

[25] Justice, C.O., Townshend, J.R.G., Holben, B.N. and Tucker, C.J. (1985) Analysis of the Phenology of Global Vegetation Using Meteorological Satellite Data. International Journal of Remote Sensing, 6, 1271-1318. https://doi.org/10.1080/01431168508948281

[26] Mather, M.P. (2004) Computer Processing of Remotely Sensed Images: An Introduction. 3rd Edition, John Wiley and Sons, Hoboken.

[27] Curtis, E., Woodcock, S., Macomber, A. and Kumar, L. (2002) Vegetation Mapping and Monitoring. In: Skidmore, A., Ed., Environmental Modeling with GIS and Remote Sensing, Taylor and Francis, UK.

[28] Wang, K., Franklin, S.E., Guo, X. and Cattet, M. (2010) Remote Sensing of Ecology, Biodiversity and Conservation: A Review from the Perspective of Remote Sensing Specialists. Sensors, 10, 9647-9667. https://doi.org/10.3390/s101109647

[29] Verbyla, D.L. (2003) Practical GIS Analysis. 2nd Edition, Taylor and Francis, UK.

[30] Harvey, F. (2008) A Primer of Fundamental: Geographic and Cartographic Concepts. The Guilford Press, New York.

[31] CBS (2008) Fifth Population Census of Sudan Results. Central Bureau of Statistics, Khartoum.

[32] El Sayem, F.E., Kafi, S.D. and Moula, F.E. (2003) Weather and Climate of Sudan. Meteorological Authority, Khartoum.

[33] Mahgoub, F. (2014) Current Status of Agriculture and Future Challenges in Sudan. Nordic Africa Institute, Current African Issues 57.

[34] Noordwijk, M.V. (1984) Ecology Textbook for the Sudan. Khartoum University Press, Khartoum.

[35] Eltahir, E.A.B. (1992) Drought Frequency Analysis of Annual Rainfall Series in Central and Western Sudan. Hydrological Sciences Journal, 37, 185-199. https://doi.org/10.1080/02626669209492581

[36] Elagib, N.A. and Alvi, S.H. (1996) Study of Hydrology and Drought in Central Sudan. Proceedings of the 2 nd International Conference in Civil Engineering on Computer Applications, Research and Practice, Vol. 2, Bahrain, 6-8 April 1996, 653-659.

[37] UNEP (1992) World Atlas of Desertification. Edward Arnold, London/New York/Melbourne/ 
Auckland, 69 Plates.

[38] Hare, F.K. (1993) Climate Variations, Drought and Desertification. WMO No. 653.

[39] Hameid, N.A. and Bannari, A. (2016) The Relationship between Vegetation and Rainfall in Central Sudan. International Journal of Remote Sensing Applications, 6, 30-40. https://doi.org/10.14355/ijrsa.2016.06.004

[40] Harrison, M.N. and Jackson, J.K. (1958) Ecological Classification of the Vegetation of the Sudan. Forest Bulletin No. 2, Forest Department, Ministry of Agriculture, Khartoum, Sudan.

[41] Achard, F., Malingreau, J.P., Phulpin, T., Saint, B., Saugier, G., Segun, B. and Vidal-Madjar, D. (1990) The Vegetation Instrument on Board SPOT-4-A Mission for Global Monitoring of the Continental Biosphere. LERTS Brochure, Toulouse.

[42] CNES (2006) SPOT-VGT User's Guide. http://www.vgt.vito.be/userguide/userguide.htm

[43] Geerken, R., Zaitchik, B. and Evans, J.P. (2005) Classifying Rangeland Vegetation Type and Coverage from NDVI Time Series Using Fourier Filtered Cycle Similarity. International Journal of Remote Sensing, 26, 5535-5554. https://doi.org/10.1080/01431160500300297

[44] Frazer, R.H., Li, Z. and Landry, R. (2000) SPOT VEGETATION for Characterizing Boreal Forest Fires. International Journal of Remote Sensing, 21, 3525-3532.

https://doi.org/10.1080/014311600750037534

[45] SPOT (2010) Link to SPOT System. SPOT Image, France. http://eoedu.belspo.be/en/satellites/spot.htm\#vegetation

[46] Khan, M.R., de Bie, C.A.J.M., van Keulen, H., Smaling, E.M. and Realc, R. (2010) Disaggregating and Mapping Crop Statistics Using Hypertemporal Remote Sensing. International Journal of Applied Earth Observation and Geoinformation, 12, 36-46. https://doi.org/10.1016/j.jag.2009.09.010

[47] Maisongrande, P., Duchemin, B. and Dedieu, G. (2004) VEGETATION/SPOT: An Operational Mission for the Earth Monitoring: Presentation of New Standard Products. International Journal of Remote Sensing, 25, 9-14. https://doi.org/10.1080/0143116031000115265

[48] Gobron, N., Pinty, B., Verstraete, M.M. and Widlowski, J.L. (2000) Development of Spectral Indices Optimized for the Vegetation Instrument. Proceedings of Vegetation 2000, Belgirate.

[49] Karl, J.W. and Maurer, B.A. (2010) Multivariate Correlations between Imagery and Field Measurements across Scales: Comparing Pixel Aggregation and Image Segmentation. Landscape Ecology, 25, 591-605. https://doi.org/10.1007/s10980-009-9439-4

[50] FAO (2003) AFRICOVER Land Cover Classification and Mapping Project, Land Cover Atlas of Sudan.

[51] Filella, I. and Penuelas, J. (1994) The Red Edge Position and Shape as Indicators of Plant Chlorophyll Content, Biomass and Hydric Status. International Journal of Remote Sensing, 15, 1459-1470. https://doi.org/10.1080/01431169408954177

[52] Richards, J.A. (2013) Remote Sensing Digital Image Analysis. Springer, Berlin. https://doi.org/10.1007/978-3-642-30062-2

[53] Lu, D., Mausel, P., Brondizio, E. and Moran, E. (2004) Change, Detection Techniques. International Journal of Remote Sensing, 25, 2365-2407.

[54] Herrmann, S.M., Anyamba, A. and Tucker, C.J. (2005) Recent Trends in Vegetation Dynamics in the African Sahel and Their Relationship to Climate. Global Environmental Change, 15, 394-404. https://doi.org/10.1016/j.gloenvcha.2005.08.004

[55] Held, I.M., Delworth, T.L., Lu, J., Findell, K.L. and Knutson, T.R. (2005) Simulation of Sa- 
hel Drought in the 20th and 21st Centuries. Proceedings of the National Academy of Sciences of the United States of America, 102, 17891-17896.

https://doi.org/10.1073/pnas.0509057102

[56] Biasutti, M. and Giannini, A. (2006) Robust Sahel Drying in Response to Late 20th Century Forcings. Geophysical Research Letters, 33, L11706. https://doi.org/10.1029/2006GL026067

[57] Naess, L.O. (2007) Adaptation to Climate Change: A Role for Local Knowledge Centre for Climate Change Research. Proceeding of Indigenous Peoples and Climate Change Symposium, Environmental Change Institute, Oxford University.

[58] Naess, L.O. (2013) The Role of Local Knowledge in Adaptation to Climate Change. Wiley Interdisciplinary Reviews. Climate Change, 4, 99-106. https://doi.org/10.1002/wcc.204

[59] Lebel, L. (2013) Local Knowledge and Adaptation to Climate Change in Natural ResourceBased Societies of the Asia Pacific. Mitigation and Adaptation Strategies for Global Change, 18, 1057-1076.

[60] Ajani, E.N., Mgbenka, R.N. and Okeke, M.N. (2013) Use of Indigenous Knowledge as a Strategy for Climate Change Adaptation among Farmers in Sub-Saharan Africa: Implications for Policy. Asian Journal of Agricultural Extension, Economics and Sociology, 2, 2340. https://doi.org/10.9734/AJAEES/2013/1856

Submit or recommend next manuscript to SCIRP and we will provide best service for you:

Accepting pre-submission inquiries through Email, Facebook, LinkedIn, Twitter, etc.

A wide selection of journals (inclusive of 9 subjects, more than 200 journals)

Providing 24-hour high-quality service

User-friendly online submission system

Fair and swift peer-review system

Efficient typesetting and proofreading procedure

Display of the result of downloads and visits, as well as the number of cited articles

Maximum dissemination of your research work

Submit your manuscript at: http://papersubmission.scirp.org/

Or contact ars@scirp.org 